\title{
Incidence of Type 2 Diabetes in Japan: A Systematic Review and Meta-Analysis
}

\author{
Atsushi Goto', Maki Goto', Mitsuhiko Noda' ${ }^{1 *}$, Shoichiro Tsugane ${ }^{2}$ \\ 1 Department of Diabetes Research, Diabetes Research Center, National Center for Global Health and Medicine, Tokyo, Japan, 2 Epidemiology and Prevention \\ Division, Research Center for Cancer Prevention and Screening, National Cancer Centre, Tokyo, Japan
}

\begin{abstract}
Background: The definition of incident type 2 diabetes varies across studies; hence, the actual incidence of type 2 diabetes in Japan is unclear. Here, we reviewed the various definitions of incident type 2 diabetes used in previous epidemiologic studies and estimated the diabetes incidence rate in Japan.

Methods: We searched for related literature in the MEDLINE, EMBASE, and Ichushi databases through September 2012. Two reviewers selected studies that evaluated incident type 2 diabetes in the Japanese population.

Results: From 1824 relevant articles, we included 33 studies with 386,803 participants. The follow-up period ranged from 2.3 to 14 years and the studies were initiated between 1980 and 2003 . The random-effects model indicated that the pooled incidence rate of diabetes was 8.8 (95\% confidence interval, 7.4-10.4) per 1000 person-years. We observed a high degree of heterogeneity in the results $\left(I^{2}=99.2 \% ; p<0.001\right)$, with incidence rates ranging from 2.3 to 52.6 per 1000 person-years. Three studies based their definition of incident type 2 diabetes on self-reports only, 10 on laboratory data only, and 20 on self-reports and laboratory data. Compared with studies defining diabetes using laboratory data $(n=30$; pooled incidence rate $=9.6 ; 95 \%$ confidence interval $=8.3-11.1$ ), studies based on selfreports alone tended to show a lower incidence rate $(n=3$; pooled incidence rate $=4.0 ; 95 \%$ confidence interval $=$ 3.2-5.0; $p$ for interaction < 0.001). However, stratified analyses could not entirely explain the heterogeneity in the results.

Conclusions: Our systematic review and meta-analysis indicated the presence of a high degree of heterogeneity, which suggests that there is a considerable amount of uncertainty regarding the incidence of type 2 diabetes in Japan. They also suggested that laboratory data may be important for the accurate estimation of the incidence of type 2 diabetes.
\end{abstract}

Citation: Goto A, Goto M, Noda M, Tsugane S (2013) Incidence of Type 2 Diabetes in Japan: A Systematic Review and Meta-Analysis. PLoS ONE 8(9): e74699. doi:10.1371/journal.pone.0074699

Editor: Yu-Kang Tu, National Taiwan University, Taiwan

Received April 25, 2013; Accepted August 2, 2013; Published September 6, 2013

Copyright: $\odot 2013$ Goto et al. This is an open-access article distributed under the terms of the Creative Commons Attribution License, which permits unrestricted use, distribution, and reproduction in any medium, provided the original author and source are credited.

Funding: This work was based on the Program to Improve Preventive Medicine by Analysis of Cohort Data Linked to Medical Records supported by Funds for integrated promotion of social system reform and research and development, from the Ministry of Education, Culture, Sports, Science and Technology. This work was also funded by Health Sciences Research Grants (Comprehensive Research on Life-Style Related Diseases including Cardiovascular Diseases and Diabetes Mellitus H22-019 and H25-016) from the Ministry of Health, Labour and Welfare of Japan. The funders had no role in study design, data collection and analysis, decision to publish, or preparation of the manuscript.

Competing interests: The authors have declared that no competing interests exist.

*E-mail: mnoda@hosp.ncgm.go.jp

\section{Introduction}

The prevalence of type 2 diabetes is increasing globally and the International Diabetes Federation has predicted that the number of people with diabetes will increase from 366 million to 552 million by 2030 [1]. Importantly, the prevalence of diabetes in Asia is rapidly increasing as $60 \%$ of the world's diabetic population are Asians [2]. In Japan, the estimated number of individuals with diabetes was approximately 6.9 million in 1997 [3], 7.4 million in 2002 [4], and 8.9 million in 2007 [5]. Although the estimates of the prevalence of diabetes have been computed from the National Health and Nutrition Survey of
Japan, the incidence rate of type 2 diabetes in Japan has not been fully clarified. Furthermore, the definition of incident type 2 diabetes varies across studies. Changes in the diagnostic criteria for diabetes may account for these discrepancies [6-8]. The American Diabetes Association (ADA), World Health Organization (WHO), and Japan Diabetes Society (JDS) lowered the fasting plasma glucose (FPG) threshold from 140 to $126 \mathrm{mg} / \mathrm{dL}$ in 1997,1998 , and 1999 , respectively $[6,8,9]$. In 2009, an International Expert Committee recommended the use of $\mathrm{HbA} 1 \mathrm{c}$ level (with a threshold of $\geq 6.5 \%(48 \mathrm{mmol} / \mathrm{mol}$ ) [10]) to diagnose diabetes, and the ADA, WHO, and JDS adopted this criterion in 2010,2011 , and 2010 , respectively 
[11-13]. However, in epidemiologic studies, measuring HbA1c or blood glucose is sometimes difficult for various reasons such as inconvenience or high costs. Therefore, several studies used self-reported diabetes as an outcome if laboratory findings were not available and self-administered questionnaires concerning diabetes history were [14,15]. However, the definition of diabetes diagnosis in epidemiologic studies remains controversial. Therefore, we conducted this systematic review and meta-analysis to estimate the incidence rate of type 2 diabetes in Japan and compile the various definitions of incident type 2 diabetes used in previous epidemiologic studies.

\section{Methods}

\section{Search Strategy}

This systematic review and meta-analysis did not have a registered review protocol, but was performed according to the recommendations of the Preferred Reporting Items for Systematic Reviews and Meta-Analyses (PRISMA) Group [16]. We searched the MEDLINE, EMBASE, and Ichushi (Japana Centra Revuo Medicina) databases through September 2012. Two reviewers selected studies that evaluated newly diagnosed type 2 diabetes among the Japanese population. The MEDLINE search terms were ("diabetes mellitus, type 2"[MeSH Terms] OR "type 2 diabetes mellitus"[All Fields] OR "type 2 diabetes"[All Fields]) AND ("risk"[MeSH Terms] OR "risk"[All Fields] OR "incidence"[MeSH Terms] OR "incidence"[All Fields]) AND ("Japan"[MeSH Terms] OR "Japan"[All Fields]). Similar search terms were used for searching the EMBASE and Ichushi databases. We further searched the references of relevant studies.

\section{Selection}

Two independent reviewers read all the retrieved abstracts and titles. The predefined inclusion criteria were as follows: 1) new-onset of type 2 diabetes reported as a study outcome and 2) study on the Japanese population. The full text of studies meeting these criteria was retrieved and screened to determine eligibility, and studies on the same participant groups were excluded. Discrepancies between the reviewers' selection were resolved by discussion.

\section{Data Extraction}

The information extracted by 2 investigators (AG and MG) was as follows: study characteristics (authors, design, year of publication, year(s) when the studies were conducted, sample size, and duration of follow-up), participants' characteristics (age and gender), outcome assessment (definition of incident diabetes), analysis strategy, and validity studies (sensitivity, specificity, positive predictive value, and negative predictive value). $\mathrm{HbA} 1 \mathrm{c}$ values are presented in percentage units as per the National Glycohemoglobin Standardization Program (NGSP) and in the units $(\mathrm{mmol} / \mathrm{mol})$ recommended by International Federation of Clinical Chemistry and Laboratory Medicine (IFCC) [17].

\section{Data Synthesis}

In studies with sufficient information on incident type 2 diabetes, we calculated the incidence rate per 1,000 personyears by dividing the number of incident diabetes cases by the duration of follow-up. When the mean follow-up duration was not available, the median was used. We used exact methods based on the Poisson distribution to compute the $95 \%$ confidence interval $(\mathrm{Cl})$ for each study [18]. The incidence rates of included studies were pooled on the log scale using inverse variance weighting and the random-effects model to calculate a pooled diabetes incidence rate and $95 \% \mathrm{Cls}$ [19]. We assessed statistical heterogeneity of incidence rates across studies using the Cochrane's $Q$ test [20] and $I^{2}$ statistic [21]. Potential publication bias was assessed using funnel plots, Begg's test [22], and Egger's test [23]. We also performed stratified analyses according to the definition of incident diabetes (selfreport vs. laboratory data), source of subjects (populationbased vs. others), areas (nonurban vs. others), mean or median follow-up period ( $\geq 5$ vs. $<5$ years), year of study initiation (before the year 2000 vs. in the year 2000 or later), and sample size $(\geq 50,000$ vs. $<50,000)$. We computed $p$ values for comparisons between subgroups using the $X^{2}$ test with one degree of freedom. To further explore potential sources of heterogeneity in the results, we conducted metaregression analyses $[24,25]$ with stratification according to year of study initiation (before the year 2000 vs. in the year 2000 or later). In the meta-regression analyses, we used the following characteristics as covariates: definition of incident diabetes (self-report vs. laboratory data), source of subjects (populationbased vs. others), follow-up period (per 5-year increase), sample size (per 10,000 increase), and areas (provincial vs. others). All analyses were performed using Stata version 12.1 (StataCorp, College Station, TX).

\section{Results}

\section{Literature Search}

Initially, we identified 1824 related articles. Based on the titles and abstracts, 62 articles were considered potentially eligible, and the entire texts of these 62 articles were evaluated. After excluding 8 studies that did not report diabetes incidence, 54 relevant studies were further assessed for their eligibility (Figure 1). Of these 54 studies, 1 study based the ascertainment of incident type 2 diabetes on adverse outcome reports [26], 1 used an overlapping population [27], 3 did not define ascertainment of type 2 diabetes [28-30], 9 were studies on prediabetes populations [31-39], 1 was a study on nonalcoholic liver fatty liver disease patients $(n=1)$ [40], 2 did not report the follow-up period [41,42], 5 did not report the number of incident diabetes cases [41-45], and 1 did not report the year of study initiation [46]. All these studies were excluded, leaving 33 studies for the meta-analysis.

\section{Study Characteristics}

The number of participants, year, and the definition of diabetes diagnosis used in the selected studies are summarized in Table 1 [14,15,47-76]. The follow-up period was $1-15$ years, and participants were followed monthly up to 


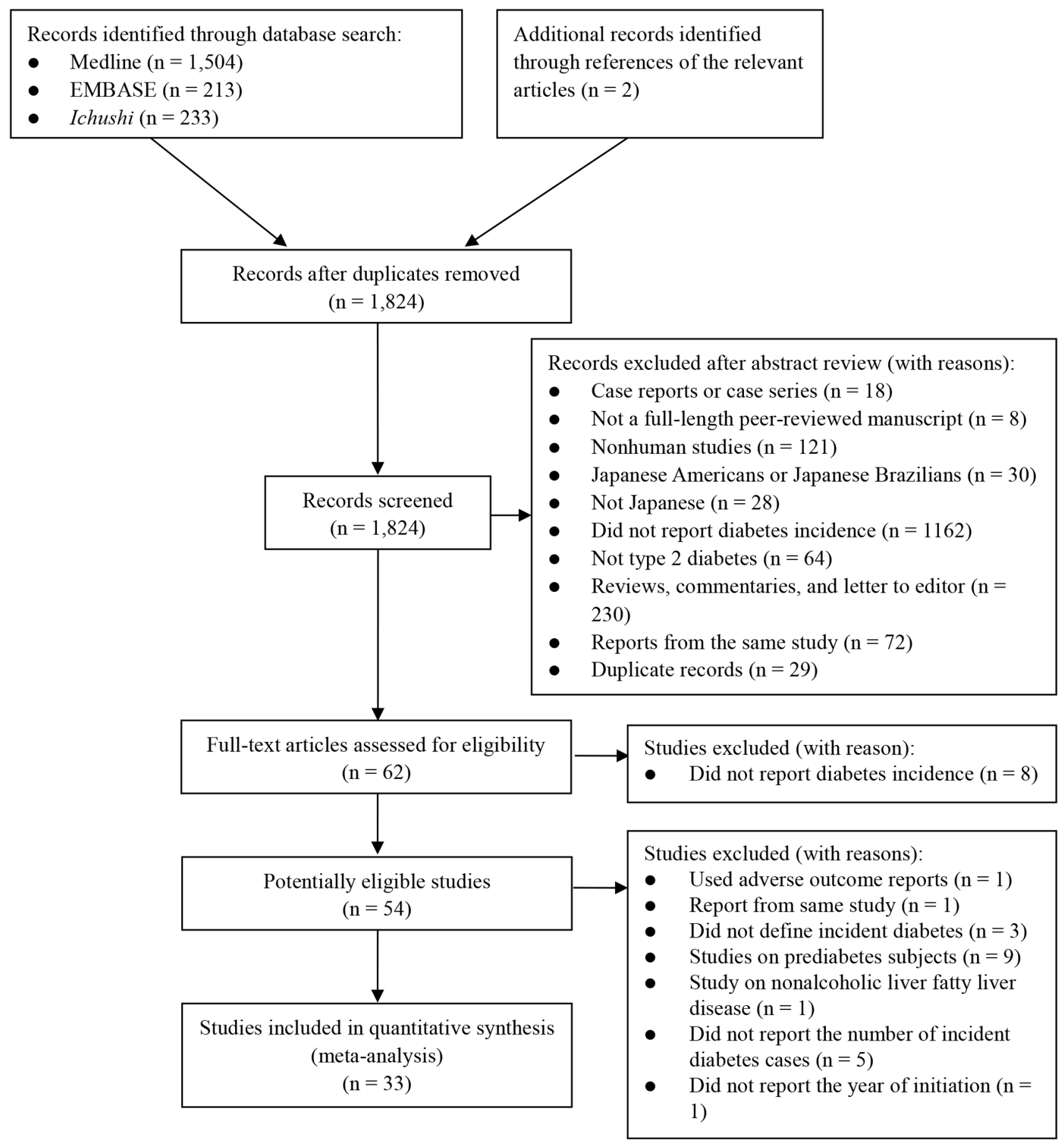

Figure 1. Literature search.

doi: 10.1371/journal.pone.0074699.g001

10 years. Three studies based the definition of incident type 2 diabetes on self-reports only $[14,47,48], 10$ on laboratory data only (fasting glucose levels, casual glucose levels, 2-h postload glucose levels after oral glucose tolerance tests, or $\mathrm{HbA} 1 \mathrm{c}$ levels) [15,49-57], and 20 on self-reports and laboratory data $[50,58-76]$. Nine studies were population-based studies
$[14,47,49,51,53,64,68,69,77]$ with participation rates varying from $40.9 \%$ to $85.3 \%$. Six studies $[48,49,51,53,68,69]$ were performed in nonurban areas. 
Table 1. Characteristics of the studies included in the systematic review.

\begin{tabular}{|c|c|c|c|c|c|c|c|c|}
\hline & Study & $\begin{array}{l}\text { Year of } \\
\text { study } \\
\text { initiation }\end{array}$ & $\begin{array}{l}\text { Sample size } \\
\text { (men, \%) }\end{array}$ & Source of subjects & $\begin{array}{l}\text { Participation } \\
\text { rate }(\%)^{*}\end{array}$ & $\begin{array}{l}\text { Mean Age } \\
\text { (range) }\end{array}$ & $\begin{array}{l}\text { Follow- } \\
\text { up, years }\end{array}$ & Definition of incident diabetes \\
\hline \multirow[t]{11}{*}{ (i) } & Laboratory data only & & & & & & & \\
\hline & Maegawa et al. [53] & 1980 & $1,338(42)$ & $\begin{array}{l}\text { Population-based (The Aito } \\
\text { Study, Aito Town, Shiga) }\end{array}$ & 79.3 & $50.0(40-64)$ & 5.6 & $\mathrm{FPG} \geq 140 \mathrm{mg} / \mathrm{dL}, 2-\mathrm{h} P G \geq 200 \mathrm{mg} / \mathrm{dL}$ \\
\hline & Tanabe et al.(1) [56] & 1980 & $230(70)$ & $\begin{array}{l}\text { Health checkups } \\
\text { (Nishikawa town, Niigata) }\end{array}$ & - & $55.9(\geq 20)$ & 4.3 & $\mathrm{FPG} \geq 126 \mathrm{mg} / \mathrm{dL}, 2-\mathrm{hPG} \geq 200 \mathrm{mg} / \mathrm{dL}$ \\
\hline & Taniguchi et al. [15] & 1981 & $6,356(100)$ & $\begin{array}{l}\text { Health checkups (The } \\
\text { Osaka Health Survey, Work } \\
\text { site, Osaka) }\end{array}$ & - & $41.5(35-60)$ & 9.7 & $\mathrm{FPG} \geq 126 \mathrm{mg} / \mathrm{dL}, 2-\mathrm{hPG} \geq 200 \mathrm{mg} / \mathrm{dL}$ \\
\hline & Kawakami et al. [52] & 1984 & $2,380(100)$ & $\begin{array}{l}\text { Health checkups (Work site, } \\
\text { Japan) }\end{array}$ & - & N.A. $(18-53)$ & 8 & $\mathrm{FPG} \geq 140 \mathrm{mg} / \mathrm{dL}, 2-\mathrm{h} P G \geq 200 \mathrm{mg} / \mathrm{dL}$ \\
\hline & Yoshinaga et al. [57] & 1986 & $1,604(80)$ & $\begin{array}{l}\text { Health checkups (Single } \\
\text { center, Tokyo) }\end{array}$ & - & $51.2(20-81)$ & 4.5 & $\mathrm{FPG} \geq 120 \mathrm{mg} / \mathrm{dL}$ more than twice \\
\hline & Nakano et al. [55] & 1991 & $435(75)$ & $\begin{array}{l}\text { Health checkups } \\
\text { (Fukushima city, } \\
\text { Fukushima) }\end{array}$ & - & $51.9(31-76)$ & 2.3 & $\mathrm{FPG} \geq 140 \mathrm{mg} / \mathrm{dL}, 2-\mathrm{h} P G \geq 200 \mathrm{mg} / \mathrm{dL}$ \\
\hline & Nakanishi et al. (1) [54] & 1994 & $1,257(100)$ & $\begin{array}{l}\text { Health checkups (Work site, } \\
\text { Osaka) }\end{array}$ & - & $46.7(35-59)$ & 5 & $\mathrm{FPG} \geq 126 \mathrm{mg} / \mathrm{dL}$ \\
\hline & Kameda et al. [51] & 1995 & $940(43)$ & $\begin{array}{l}\text { Population-based (The } \\
\text { Funagata Study, Funagata } \\
\text { Town, Yamagata) }\end{array}$ & 40.9 & 58.2 (N.A.) & 5 & $\mathrm{FPG} \geq 140 \mathrm{mg} / \mathrm{dL}, 2-\mathrm{h} P G \geq 200 \mathrm{mg} / \mathrm{dL}$ \\
\hline & Doi et al. [49] & 2002 & $2,164(40)$ & $\begin{array}{l}\text { Population-based (The } \\
\text { Hisayama Study, Hisayama } \\
\text { Town, Fukuoka) }\end{array}$ & 77.0 & $58.6(40-79)$ & 6 & $\mathrm{FPG} \geq 126 \mathrm{mg} / \mathrm{dL}, 2-\mathrm{h} P G \geq 200 \mathrm{mg} / \mathrm{dL}$ \\
\hline & Fujita et al.(1) [50] & 2002 & $27,760(26)$ & $\begin{array}{l}\text { Health checkups (Kashiwa } \\
\text { City, Chiba) }\end{array}$ & - & $61.8(40-79)$ & 4 & $\begin{array}{l}\mathrm{FPG} \geq 126 \mathrm{mg} / \mathrm{dL}, \mathrm{HbA} 1 \mathrm{c} \geq 6.9 \%(52 \\
\mathrm{mmol} / \mathrm{mol})\end{array}$ \\
\hline \multirow[t]{12}{*}{ (ii) } & $\begin{array}{l}\text { Laboratory data and } \\
\text { self-reports of } \\
\text { diagnosis/treatment } \\
\end{array}$ & & & & & & & \\
\hline & Sawada et al. [74] & 1985 & 4,187 (men) & $\begin{array}{l}\text { Health checkups (Work } \\
\text { site, Tokyo) }\end{array}$ & - & $32.0(22-40)$ & 14 & $\begin{array}{l}\mathrm{FPG} \geq 126 \mathrm{mg} / \mathrm{dL}, 2-\mathrm{h} P G \geq 200 \\
\mathrm{mg} / \mathrm{dL} \text {, diabetes treatment }\end{array}$ \\
\hline & Nagaya et al. [65] & 1988 & $25,196(67)$ & $\begin{array}{l}\text { Health checkups (Single } \\
\text { center, Gifu) }\end{array}$ & - & $43.8(30-59)$ & 7.3 & $\begin{array}{l}\text { Fasting serum glucose } \geq 126 \mathrm{mg} / \mathrm{dL} \text {, } \\
\text { diabetes treatment }\end{array}$ \\
\hline & Okada et al. [69] & 1989 & $717(38)$ & $\begin{array}{l}\text { Population-based } \\
\text { (Yaeyama district, } \\
\text { Okinawa) }\end{array}$ & 58.9 & $55.0(30-89)$ & 10 & $\begin{array}{l}\mathrm{FPG} \geq 126 \mathrm{mg} / \mathrm{dL}, 2-\mathrm{h} P G \geq 200 \\
\mathrm{mg} / \mathrm{dL}, \mathrm{HbA} 1 \mathrm{c} \geq 6.9 \%(52 \mathrm{mmol} / \mathrm{mol}) \text {, } \\
\text { diabetes treatment }\end{array}$ \\
\hline & Sairenchi et al. [70] & 1993 & $128,141(31)$ & Health checkups (Ibaraki) & - & N.A. $(40-79)$ & 4.8 & $\begin{array}{l}\mathrm{FPG} \geq 126 \mathrm{mg} / \mathrm{dL} \text {, casual } \mathrm{PG} \geq 200 \\
\mathrm{mg} / \mathrm{dL} \text {, diabetes treatment }\end{array}$ \\
\hline & Fujita et al.(2) [50] & 1994 & $35,579(21)$ & $\begin{array}{l}\text { Health checkups (Chiba } \\
\text { City, Chiba) }\end{array}$ & - & $56.3(40-79)$ & 10.2 & $\begin{array}{l}\mathrm{FPG} \geq 126 \mathrm{mg} / \mathrm{dL} \text {, casual } \mathrm{PG} \geq 200 \\
\mathrm{mg} / \mathrm{dL} \text {, self-reports of diagnosis }\end{array}$ \\
\hline & Nakanishi et al. (2) [66] & 1994 & $3,260(100)$ & $\begin{array}{l}\text { Health checkups (Work } \\
\text { site, Japan) }\end{array}$ & - & N.A. $(35-59)$ & 7 & $\mathrm{FPG} \geq 126 \mathrm{mg} / \mathrm{dL}$, diabetes treatment \\
\hline & Ohnishi et al. [68] & 1994 & $827(40)$ & $\begin{array}{l}\text { Population-based (The } \\
\text { Tanno and Sobetsu Study, } \\
\text { towns of Tanno and } \\
\text { Sobetsu, Hokaido) }\end{array}$ & N.A. & N.A. $(40-64)$ & 10 & FPG $\geq 126 \mathrm{mg} / \mathrm{dL}$, diabetes treatment \\
\hline & Sanada et al. [72] & 1994 & $1,554(62)$ & $\begin{array}{l}\text { Health checkups }(2 \\
\text { centers, Fukushima) }\end{array}$ & - & $50.4(23-80)$ & 10 & $\begin{array}{l}\mathrm{FPG} \geq 126 \mathrm{mg} / \mathrm{dL}, 2-\mathrm{h} P G \geq 200 \\
\mathrm{mg} / \mathrm{dL} \text {, diabetes treatment }\end{array}$ \\
\hline & Inoue et al. [61] & 1995 & $449(76)$ & $\begin{array}{l}\text { Health checkups (Work } \\
\text { site, Japan) }\end{array}$ & - & $45.6(23-65)$ & 7 & $\begin{array}{l}\text { FPG } \geq 126 \mathrm{mg} / \mathrm{dL} \text {, diabetes treatment, } \\
\text { self-reports of diagnosis }\end{array}$ \\
\hline & Heianza et al. [60] & 1997 & $6,241(75)$ & $\begin{array}{l}\text { Health checkups (The } \\
\text { TOPICS, Single center, } \\
\text { Tokyo) }\end{array}$ & - & $49.9(24-82)$ & 4.7 & $\begin{array}{l}\mathrm{FPG} \geq 126 \mathrm{mg} / \mathrm{dL}, \mathrm{HbA} 1 \mathrm{c} \geq 6.5 \% \text { (48 } \\
\mathrm{mmol} / \mathrm{mol})\end{array}$ \\
\hline & Fukui et al. [58] & 1998 & $4,153(59)$ & $\begin{array}{l}\text { Health checkups (Single } \\
\text { center, Kyoto) }\end{array}$ & - & 48.2 (N.A.) & 8.2 & FPG $\geq 126 \mathrm{mg} / \mathrm{dL}$, diabetes treatment \\
\hline
\end{tabular}


Table 1 (continued).

\begin{tabular}{|c|c|c|c|c|c|c|c|c|}
\hline & Study & $\begin{array}{l}\text { Year of } \\
\text { study } \\
\text { initiation }\end{array}$ & $\begin{array}{l}\text { Sample size } \\
\text { (men, \%) }\end{array}$ & Source of subjects & $\begin{array}{l}\text { Participation } \\
\text { rate }(\%)^{*}\end{array}$ & $\begin{array}{l}\text { Mean Age } \\
\text { (range) }\end{array}$ & $\begin{array}{l}\text { Follow- } \\
\text { up, years }\end{array}$ & Definition of incident diabetes \\
\hline & Nomura et al. [67] & 1998 & $9,322(51)$ & $\begin{array}{l}\text { Health checkups (Work site, } \\
\text { Japan) }\end{array}$ & - & $51.5(19-69)$ & 6 & $\begin{array}{l}\mathrm{FPG} \geq 126 \mathrm{mg} / \mathrm{dL}, \mathrm{HbA} 1 \mathrm{c} \geq 6.5 \% \text {, } \\
\text { diabetes treatment }\end{array}$ \\
\hline & Tanabe et al.(2) [75] & 1998 & $6,775(32)$ & $\begin{array}{l}\text { Health checkups (Tokachimachi } \\
\text { City, Niigata) }\end{array}$ & - & $62.0(40-89)$ & 5 & $\begin{array}{l}\mathrm{FPG} \geq 126 \mathrm{mg} / \mathrm{dL} \text {, casual PG } \geq 200 \\
\mathrm{mg} / \mathrm{dL}, \mathrm{HbA} 1 \mathrm{c} \geq 6.9 \% \text { ( } 52 \mathrm{mmol} / \\
\mathrm{mol} \text { ), self-reports of diagnosis }\end{array}$ \\
\hline & Hayashino et al. [59] & 1999 & $4,975(100)$ & $\begin{array}{l}\text { Health checkups (The HIIPOP- } \\
\text { OHP Study, Work site, Japan) }\end{array}$ & - & $38.3(19--69)$ & 3.4 & $\begin{array}{l}\mathrm{FPG} \geq 126 \mathrm{mg} / \mathrm{dL} \text {, casual } \mathrm{PG} \geq 200 \\
\mathrm{mg} / \mathrm{dL} \text {, diabetes treatment, self- } \\
\text { reports of diagnosis }\end{array}$ \\
\hline & Kato et al. [62] & 2000 & $11,369(29)$ & $\begin{array}{l}\text { Health checkups (The Omiya } \\
\text { MA Cohort Study, Omiya City, } \\
\text { Saitama) }\end{array}$ & - & $62(55-68)$ & 7 & $\begin{array}{l}\mathrm{FPG} \geq 126 \mathrm{mg} / \mathrm{dL} \text {, diabetes } \\
\text { treatment, self-reports of diagnosis }\end{array}$ \\
\hline & Sato et al. [73] & 2000 & $\begin{array}{l}10,631 \\
(100)\end{array}$ & $\begin{array}{l}\text { Health checkups (The Kansai } \\
\text { Healthcare Study, Work site, } \\
\text { Kansai district) }\end{array}$ & - & $47.9(40-55)$ & 4 & $\begin{array}{l}\mathrm{FPG} \geq 126 \mathrm{mg} / \mathrm{dL} \text {, diabetes } \\
\text { treatment }\end{array}$ \\
\hline & Muraki et al. [64] & 2001 & 4,398 (36) & $\begin{array}{l}\text { Population-based (The CIRCS, } \\
5 \text { areas, Japan) }\end{array}$ & N.A. & $57.6(40-69)$ & 3 & $\begin{array}{l}\text { Fasting serum glucose } \geq 126 \mathrm{mg} / \mathrm{dL} \text {, } \\
\text { casual serum glucose } \geq 200 \mathrm{mg} / \mathrm{dL} \text {, } \\
\text { diabetes treatment }\end{array}$ \\
\hline & Li et al. [63] & 2002 & $3,008(77)$ & $\begin{array}{l}\text { Health checkups (Work site, } \\
\text { Aichi) }\end{array}$ & - & $47.3(35-66)$ & 6 & $\begin{array}{l}\text { Fasting glucose } \geq 126 \mathrm{mg} / \mathrm{dL} \text {, self- } \\
\text { reports of diagnosis }\end{array}$ \\
\hline & Sakurai et al. [71] & 2003 & $1,995(100)$ & $\begin{array}{l}\text { Health checkups (Work site, } \\
\text { Toyama) }\end{array}$ & - & $46.0(35-55)$ & 4.5 & $\begin{array}{l}\mathrm{FPG} \geq 126 \mathrm{mg} / \mathrm{dL}, 2-\mathrm{h} P G \geq 200 \\
\mathrm{mg} / \mathrm{dL} \text {, diabetes treatment }\end{array}$ \\
\hline & Totsuka et al. [76] & 2003 & $172(70)$ & $\begin{array}{l}\text { Health checkups (Single center, } \\
\text { Tsukuba City, Ibaraki) }\end{array}$ & - & $49.4(31-62)$ & 3 & $\begin{array}{l}\mathrm{FPG} \geq 126 \mathrm{mg} / \mathrm{dL}, 2-\mathrm{hPG} \geq 200 \\
\mathrm{mg} / \mathrm{dL} \text {, self-reports of diagnosis }\end{array}$ \\
\hline (iii) & $\begin{array}{l}\text { Self-reports of } \\
\text { diabetes diagnosis } \\
\text { only }\end{array}$ & & & & & & & \\
\hline & Iso et al. [47] & 1988 & $17,413(39)$ & $\begin{array}{l}\text { Population-based (The JACC } \\
\text { Study, } 45 \text { areas, Japan) }\end{array}$ & 83 & $53.2(40-79)$ & 5 & Self-reports of diagnosis \\
\hline & Kurotani et al. [14] & 1995 & $48,437(44)$ & $\begin{array}{l}\text { Population-based (The JPHC } \\
\text { Study, } 11 \text { areas, Japan) }\end{array}$ & 81 & $50.7(40-69)$ & 5 & Self-reports of diagnosis \\
\hline & Oba et al. [48] & 1992 & $13,540(44)$ & $\begin{array}{l}\text { Population-based (The } \\
\text { Takayama Study, Takayama } \\
\text { City, Gifu) }\end{array}$ & 85.3 & $51.6(\geq 35)$ & 10 & Self-reports of diagnosis \\
\hline
\end{tabular}

Abbreviations:

* Participation rates in population-based studies are shown.

\section{Incidence Rate of Type 2 Diabetes}

The 33 studies included 386,803 participants. The randomeffects model indicated that the pooled incidence rate of diabetes was $8.8(95 \% \mathrm{Cl}=7.4-10.4)$ per 1,000 person-years (Figure 2). There was little evidence of publication bias. The funnel plot did not indicate asymmetry; Begg's $p$ value was 0.45 ; and Egger's bias coefficient was $-3.98(95 \% \mathrm{Cl}$, -9.72-1.77; $p=0.17$ ) (not shown). We observed a high degree of heterogeneity $\left(I^{2}=99.2 \% ; p<0.001\right)$, with incidence rates ranging from 2.3 to 52.6 per 1000 person-years. We also performed stratified analyses according to the definition of incident diabetes (self-reports vs. laboratory data), source of subjects (population-based vs. others), areas (nonurban vs. others), mean or median follow-up period ( $\geq 5$ vs. $<5$ years), year of study initiation (before the year 2000 vs. in the year
2000 or later 2000 ), and sample size ( $\geq 50,000$ vs. $<50,000$ ) (Table 2). The studies using self-reports of diabetes alone for diabetes diagnosis showed a lower diabetes incidence rate $(\mathrm{N}$ of studies $=3$; pooled incidence rate $=4.0 ; 95 \%$ confidence interval $=3.2-5.0 ; p$ for interaction $<0.001)$ than did the studies using laboratory data $(\mathrm{N}$ of studies $=30$; pooled incidence rate $=9.6 ; 95 \% \mathrm{Cl}=8.3-11.1)$. The studies with longer follow-up periods ( $\geq 5$ years) showed lower incidence rate estimates of diabetes $(\mathrm{N}$ of studies $=22$; pooled incidence rate $=6.6 ; 95 \%$ $\mathrm{Cl}=5.5-8.0 ; \mathrm{p}$ for interaction $<0.001)$ than did the studies with shorter follow-up periods $(<5$ years; $\mathrm{N}$ of studies $=11$; pooled incidence rate $=16.3,95 \% \mathrm{Cl}=14.0-18.9)$. The studies that initiated before the year 2000 ( $N$ of studies $=25$ ) reported lower estimates of incidence rates (pooled incidence rate $=7.8 ; 95 \%$ $\mathrm{Cl}=6.2-9.5 ; \mathrm{p}$ for interaction $=0.001)$ than did the studies that initiated in the year 2000 or later $(\mathrm{N}$ of studies $=8$; pooled 


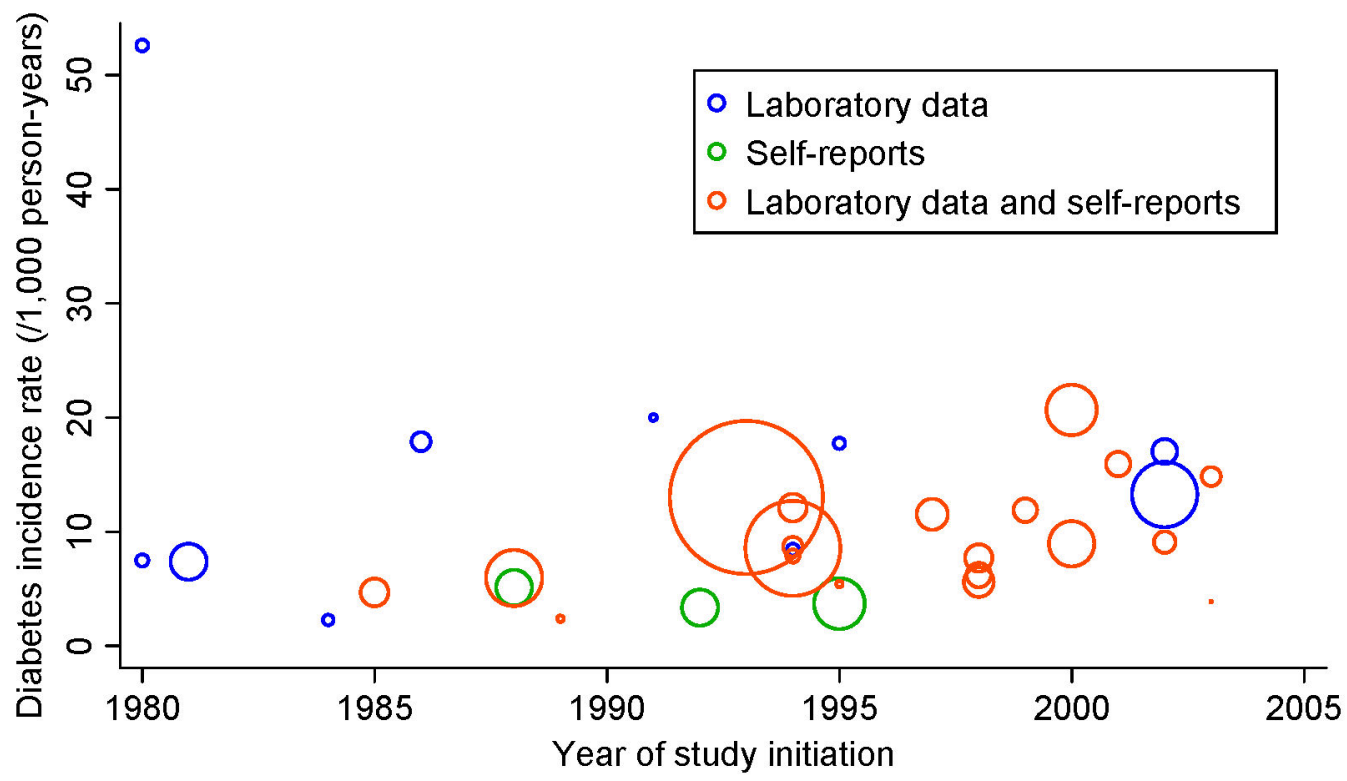

Figure 2. Forest plots of diabetes incidence rate. $\mathrm{Cl}$ indicates confidence interval.Dots indicate diabetes incidence rates. Horizontal lines indicate $95 \%$ Cls for incidence rates. The diamonds represent the pooled incidence rate estimates with $95 \%$ Cls. doi: 10.1371/journal.pone.0074699.g002

incidence rate $=13.4 ; 95 \% \mathrm{Cl}=10.4-17.1)$. Figure 3 shows a bubble plot of the diabetes incidence rate per 1,000 personyears as a function of the year of study initiation. The results indicated that more recent studies tended to show higher incidence rate estimates. However, stratification according to these characteristics could not entirely explain the heterogeneity in the results, with $\mathrm{I}^{2}$ statistics being high within each stratum. We also conducted meta-regression analyses to further explore the sources of heterogeneity (Table 3). Metaregression analyses indicated that a longer follow-up period was associated with lower incidence rates in studies before the year 2000; however, it explained only a small proportion of the heterogeneity (adjusted $\mathrm{R}^{2}$ statistics $=22.1 \%$; residual $\mathrm{I}^{2}$ statistics $=99.1 \%$ ). In addition, we estimated the pooled incidence rate of diabetes in the studies on prediabetes populations. The incidence rate among prediabetes populations (pooled incidence rate $=49.2$ per 1,000 personyears; $95 \% \mathrm{Cl}=31.5-76.8$ ) (not shown) [31,32,34-39] was much higher than that among total populations (pooled incidence rate $=8.8$ per 1,000 person-years).

\section{Validity of Self-reported Diabetes}

Among the studies that considered self-reports for the definition of diabetes diagnosis, 3 conducted validity studies among participants whose laboratory data were available $[14,47,63]$. In the Japan Collaborative Cohort Study for Evaluation of Cancer Risk Study (JACC Study), self-reports were compared with laboratory data and treatment status in a subsample of study participants [47]. In the Japan Public Health Center-based prospective Study (JPHC Study) [14], self-reports were compared with medical records and laboratory data retrieved from health checkups $[78,79]$. In the study by $\mathrm{Li}$ et al [63], self-reports were compared with laboratory data and reports from the physicians of study participants [80]. Their positive predictive values, negative predictive values, sensitivity, and specificity were $95.7 \%-99.2 \%, 93.8 \%-96.3 \%, 70 \%-82.6 \%$, and $95 \%-99.7 \%$, respectively $[47,78,80]$. Because these validation studies were conducted among participants whose laboratory data were available, validity of self-reports among those who had not visited health checkups remains unclear.

\section{Discussion}

In the present systematic review and meta-analysis of studies that evaluated new-onset type 2 diabetes in the Japanese population, we found that there was a high degree of heterogeneity in the incidence of diabetes in Japan and an increasing number recent studies tended to show higher incidence rate estimates. Our study also indicated that studies that used self-reported diagnosed diabetes tended to show a lower incidence rate than studies that used laboratory data, suggesting that laboratory data are important for the accurate estimation of the incidence rate of diabetes. In addition, the studies with longer follow-up durations tended to show lower incidence rates. In the cohorts with longer follow-up durations, individuals who did not develop diabetes at earlier stages of study period were likely less predisposed toward diabetes and would have had a lower likelihood of developing diabetes later in the study, which might have led to the lower overall incidence rates in the studies with follow-up durations that were longer than those of the others. Although we observed a high degree of heterogeneity between studies, stratified analyses or 
Table 2. Stratified analysis of the incidence rate of diabetes.

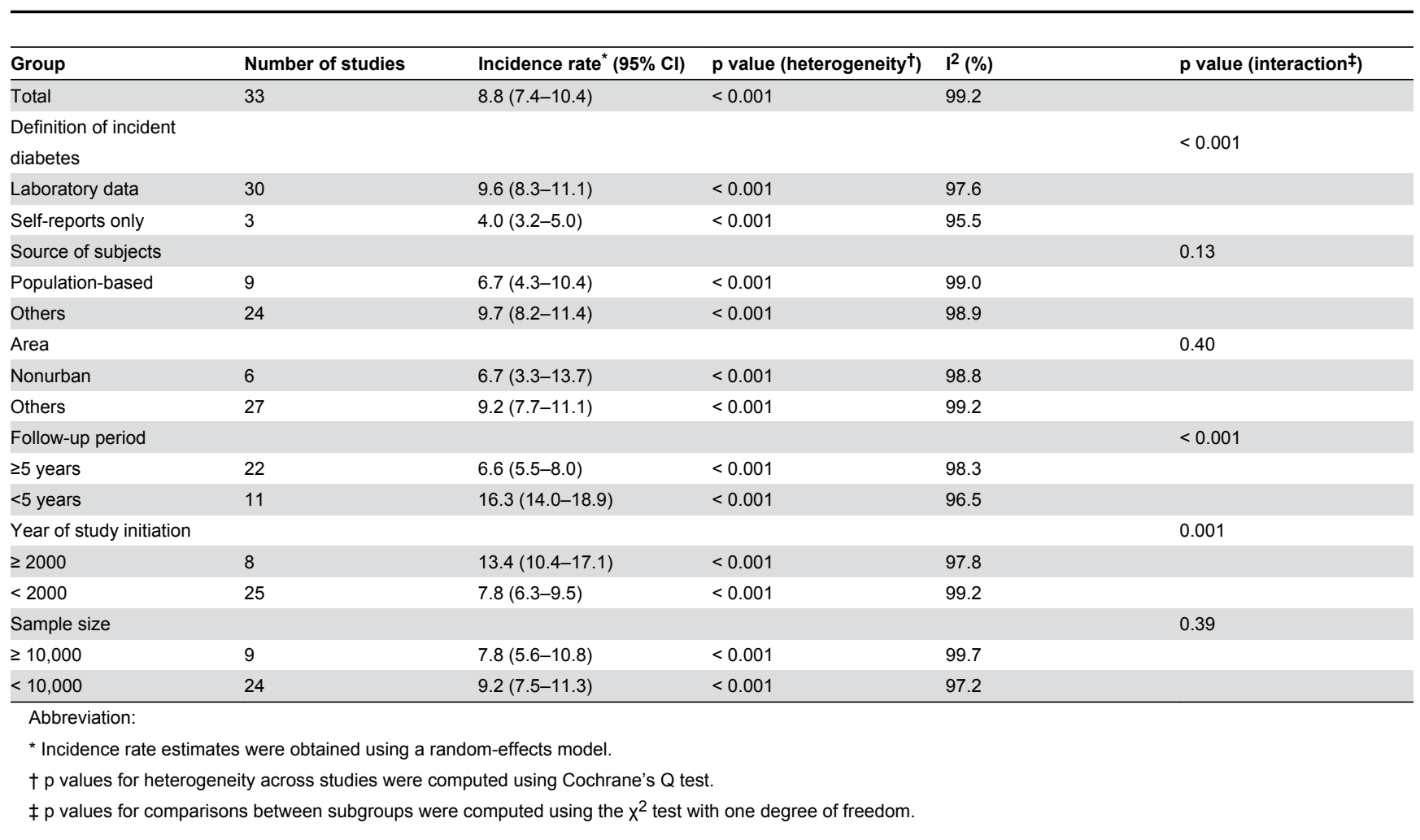

meta-regression analyses did not identify major sources of the heterogeneity.

The overall incidence rate of diabetes in Japan was found to be 9.0 per 1,000 person-years. This estimate is slightly higher than the self-report-based $[81,82]$ or administrative databasebased [83] estimates from the U.S. [81], U.K. [83], and China [82]. The U.S. National Health Interview Survey reported that the incidence rate of medically diagnosed diabetes was 8.4 per 1,000 person-years among men and 8.1 per 1,000 personyears among women in 2008 [81]. Using a primary care medical records database in the U.K, the incidence rate of diabetes in the U.K. was reported to be 4.4 per 1,000 personyears in 2005 [83]. In addition, the Shanghai Diabetes Study reported that diabetes incidence rate identified by self-reports was 6.0 per 1,000 person-years among Chinese women in Shanghai [82]. However, because estimates based on selfreports or administrative databases would have overlooked undiagnosed or untreated diabetes, these studies may have underestimated the incidence rate. Indeed, our overall estimate of diabetes incidence in Japan was mainly driven by the incidence rates from studies using laboratory data. The overall rate (9.0 per 1,000 person-years) was close to that observed in the study among Australians, in which diabetes was defined by fasting plasma glucose levels $\geq 126 \mathrm{mg} / \mathrm{dL}$ and/or diabetes diagnosed by physicians [84]. In the Blue Mountains Eye Study, the incidence rate of type 2 diabetes was 9.3 per 1,000 person-years among non-Aboriginal Australians [84]. Further studies that standardize the definition of incident diabetes are required to compare the incidence rate of diabetes between countries.

Diabetes is often defined exclusively on the basis of selfreports $[85,86]$. In the present review, we found that studies based on self-reports alone tended to show a lower incidence rate compared with studies based on laboratory data, suggesting that laboratory data are important to estimate the incidence rate of diabetes correctly. Three studies conducted validation studies among participants whose laboratory data were available; the range for the specificity of self-reports as obtained in this review (95-99.7\%) was relatively high. In studies based on self-reports, diabetes incidence may have been underestimated probably because the sensitivity was not sufficiently high. Moreover, the validity of self-reports among those who had not visited health checkups is unclear. In particular, the sensitivity of self-reports among participants who had not been screened for diabetes may be much lower than the range $(70 \%-82.6 \%)$ obtained in this review. Of note, laboratory data were not available in any of the large-scale population-based studies $[14,47,77]$. This seems to indicate that multiple sources of evidence including self-reports, claimbased data, hospital admission data, and mortality data should be considered in such situations.

Our study also indicated that the incidence of type 2 diabetes in Japan may be increasing. The FPG threshold was lowered from $\geq 140$ to $\geq 126 \mathrm{mg} / \mathrm{dl}$ by the ADA, WHO, and JDS in 1997 , 1998 , and 1999 , respectively $[6,8,9]$; this may have reflected the change in the diagnoses and incidence rates of diabetes. The increase in obesity prevalence [87], decline in physical 


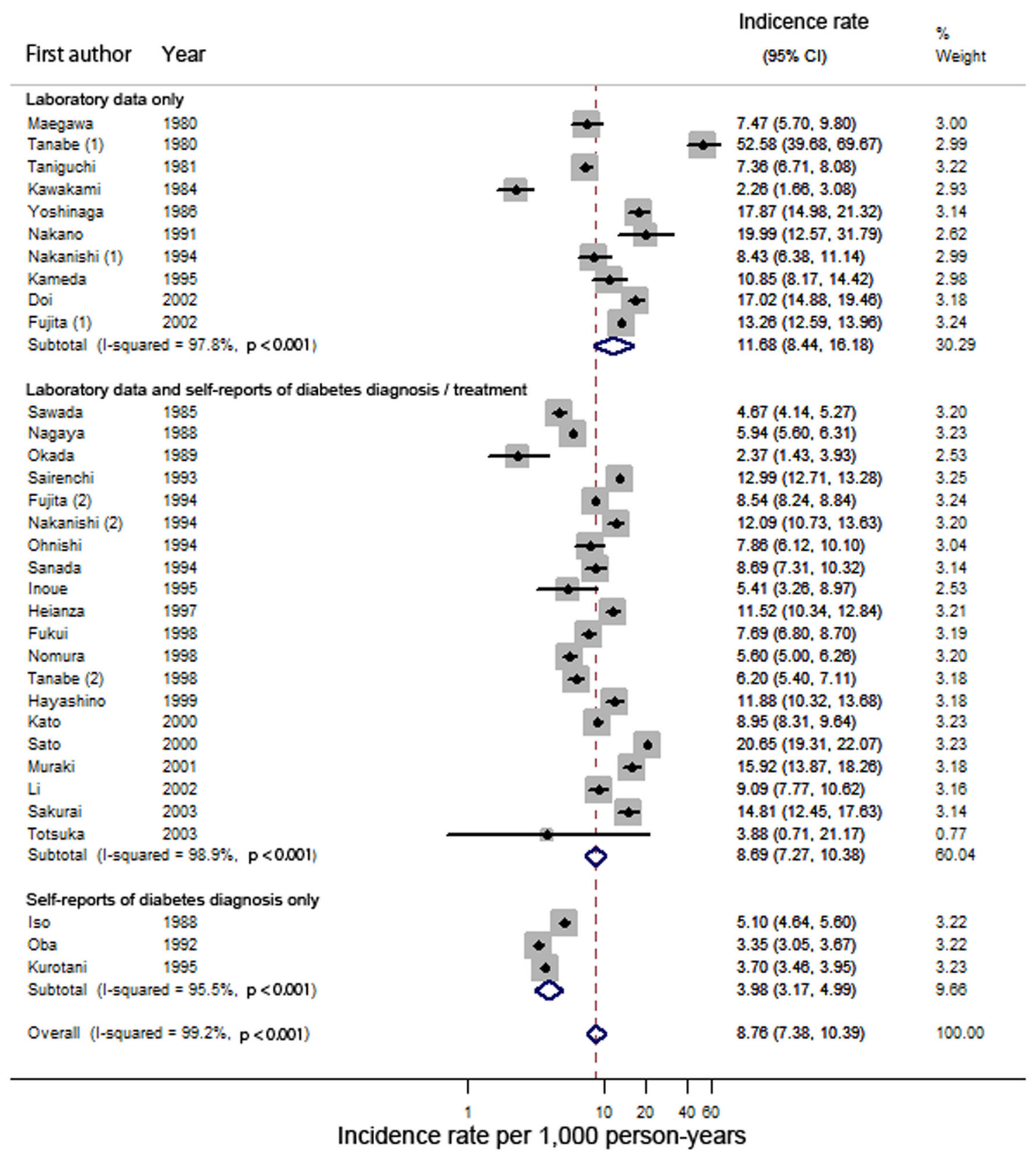

Figure 3. Bubble plots of diabetes incidence rate against the year of study initiation. A bubble shows a study, and the size of the bubble is proportional to the inverse of the variance of the log-transformed incidence rate. Diabetes incidence rate was calculated by dividing the number of new-onset diabetes cases by the duration of follow-up. When the mean follow-up duration was not available, the median was used.

doi: 10.1371/journal.pone.0074699.g003

activity [5], and population aging [88] may also explain possible trend toward an increasing rate of diabetes incidence in Japan. 
Table 3. Meta-regression analyses of the incidence rate of diabetes with stratification according to year of study initiation (before the year 2000 vs. in the year 2000 or later).

\begin{tabular}{|c|c|c|c|c|}
\hline Study characteristic & $\begin{array}{l}\text { Ratio of } \\
\text { incidence rate } \\
(95 \% \mathrm{Cl})\end{array}$ & p value & $\begin{array}{l}\text { Adjusted } \\
\mathrm{eR}^{2}\end{array}$ & $\begin{array}{l}\text { Residual }\left.\right|^{2} \\
(\%)\end{array}$ \\
\hline \multicolumn{5}{|l|}{ Studies before the year } \\
\hline Self-reports only & $0.47(0.21-1.04)$ & 0.06 & 12.4 & 98.6 \\
\hline Population-based & $0.57(0.32-1.03)$ & 0.06 & 11.3 & 98.7 \\
\hline Nonurban areas & $0.66(0.33-1.33)$ & 0.24 & 1.7 & 99.2 \\
\hline $\begin{array}{l}5 \text {-year increase in follow-up } \\
\text { period }\end{array}$ & $0.55(0.35-0.86)$ & 0.01 & 22.1 & 99.1 \\
\hline $\begin{array}{l}\text { 5-year increase in year of } \\
\text { study initiation }\end{array}$ & $0.96(0.75-1.23)$ & 0.73 & -4.1 & 99.3 \\
\hline $\begin{array}{l}10,000 \text { increase in sample } \\
\text { size }\end{array}$ & $1.00(0.90-1.12)$ & 0.94 & -4.8 & 98.7 \\
\hline \multicolumn{5}{|l|}{$\begin{array}{l}\text { Studies in the year } 2000 \\
\text { or later }(N=8)\end{array}$} \\
\hline Population-based & $1.33(0.67-2.64)$ & 0.35 & -1.4 & 98.0 \\
\hline Nonurban areas & $1.32(0.52-3.34)$ & 0.49 & -9.5 & 98.1 \\
\hline $\begin{array}{l}5 \text {-year increase in follow-up } \\
\text { period }\end{array}$ & $0.54(0.19-1.51)$ & 0.19 & 31.1 & 96.3 \\
\hline $\begin{array}{l}\text { 5-year increase in year of } \\
\text { study initiation }\end{array}$ & $0.82(0.17-3.96)$ & 0.76 & -21.4 & 98.1 \\
\hline $\begin{array}{l}10,000 \text { increase in sample } \\
\text { size }\end{array}$ & $1.00(0.68-1.49)$ & 0.98 & -21.4 & 98.1 \\
\hline $\begin{array}{l}\text { Abbreviation: } \\
\text { * Incidence rate with } \\
\text { characteristic. Ratios }<1 \text { co } \\
\text { the characteristic. }\end{array}$ & $\begin{array}{l}\text { characteristic divi } \\
\text { orrespond to a sma }\end{array}$ & $\begin{array}{l}\text { ded by } \\
\text { ller incid }\end{array}$ & $\begin{array}{l}\text { incidence } \\
\text { dence rate } f\end{array}$ & $\begin{array}{l}\text { rate without } \\
\text { r studies with }\end{array}$ \\
\hline
\end{tabular}

Future studies using the standardized definition of incident type 2 diabetes are warranted to clarify the trend in the incidence of diabetes in Japan.

\section{References}

1. Whiting DR, Guariguata L, Weil C, Shaw J (2011) IDF diabetes atlas: global estimates of the prevalence of diabetes for 2011 and 2030. Diabetes Res Clin Pract 94: 311-321. doi:10.1016/j.diabres. 2011.10.029. PubMed: 22079683

2. Chan JC, Malik V, Jia W, Kadowaki T, Yajnik CS et al. (2009) Diabetes in Asia: epidemiology, risk factors, and pathophysiology. JAMA 301: 2129-2140. doi:10.1001/jama.2009.726. PubMed: 19470990.

3. Ministry of Health (1997) National Diabetes Survey. Available: http:// www.mhlw.go.jp/toukei/kouhyo/indexkk 4 1.html. Accessed 23 August 2012.

4. Ministry of Health, Labour and Welfare (2002) National Diabetes Survey. Available: http://www.mhlw.go.jp/shingi/2004/03/ s0318-15.html\#tyosa. Accessed 23 August 2012.

5. Ministry of Health, Labour and Welfare (2007) National Health and Nutrition Survey. Available: http://www.mhlw.go.jp/bunya/kenkou/ eiyou09/01.html. Accessed 23 August 2012.

6. Alberti KG, Zimmet PZ (1998) Definition, diagnosis and classification of diabetes mellitus and its complications. Part 1: diagnosis and classification of diabetes mellitus provisional report of a WHO consultation. Diabet Med 15: 539-553. doi:10.1002/ (SICI)1096-9136(199807)15:7. PubMed: 9686693.

7. American Diabetes Association (2013) Diagnosis and classification of diabetes mellitus. Diabetes Care 36 Suppl 1: S67-S74. doi:10.2337/ dc13-S067. PubMed: 23264425
The strengths of this study include its large sample size and comprehensive assessment of definitions used to identify incident type 2 diabetes. Several limitations also exist. First, we limited our search to the Japanese population, which limits the generalizability our findings. Second, we did not have individual participant data or age- and gender-specific estimates of type 2 diabetes incidence. Therefore, we were not able to compute age-standardized incidence rates. Third, although we searched 3 large electronic databases (MEDLINE, EMBASE, and Ichushi [the largest database for medical literature in Japan]), we may have missed some related studies. Finally, large regional differences in diabetes incidence may exist, but we were unable to establish a region-specific estimate.

\section{Conclusions}

Our systematic review and meta-analysis indicated the presence of a high degree of heterogeneity, which suggests that there is a considerable amount of uncertainty regarding the incidence of type 2 diabetes in Japan. They also suggested that laboratory data may be important to identify undiagnosed diabetes. Future studies should aim to standardize the definition of incident diabetes in order to compare the incidence rate of type 2 diabetes between countries

\section{Supporting Information}

Checklist S1. (DOCX)

\section{Author Contributions}

Conceived and designed the experiments: AG MG MN ST. Performed the experiments: AG MG. Analyzed the data: AG MG. Contributed reagents/materials/analysis tools: AG MG MN ST. Wrote the manuscript: AG MG. Critical revision of the manuscript for important intellectual contents: MN ST.

8. Kuzuya T, Nakagawa S, Satoh J, Kanazawa Y, Iwamoto Y et al. (1999) Report of the committee of Japan Diabetes Society on the classification and diagnostic criteria of diabetes mellitus. J Japan Diab Soc 42: 385-404

9. American Diabetes Association (1997) Report of the expert committee on the diagnosis and classification of diabetes mellitus. Diabetes Care 20: 1183-1197. PubMed: 9203460.

10. International Expert $C$ (2009) International Expert Committee report on the role of the A1C assay in the diagnosis of diabetes. Diabetes Care $32(1327-1334)$

11. American Diabetes Association (2010) Diagnosis and classification of diabetes mellitus. Diabetes Care 33 Suppl 1: S62-S69. doi:10.2337/ dc10-S062. PubMed: 20042775.

12. World Health Organization (2011) Use of glycated haemoglobin $(\mathrm{HbA} 1 \mathrm{c})$ in the diagnosis of diabetes mellitus. Abbreviated report of a WHO consultation. Geneva: WHO. pp. 1-25.

13. Seino $Y$, Nanjo K, Tajima N, Kadowaki T, Kashiwagi A et al. (2010) Report of the committee on the classification and diagnostic criteria of diabetes mellitus. J Diabetes Invest 1: 212-228. doi:10.1111/j. 2040-1124.2010.00074.x

14. Kurotani K, Nanri A, Goto A, Mizoue T, Noda M et al. (2013) Vegetable and fruit intake and risk of type 2 diabetes: Japan Public Health Centerbased Prospective Study. $\mathrm{Br} \mathrm{J}$ Nutr 109: 709-717. doi:10.1017/ S0007114512001705. PubMed: 22571826. 
15. Taniguchi $\mathrm{Y}$, Hayashi T, Tsumura K, Endo G, Fujii S et al. (2001) Serum uric acid and the risk for hypertension and Type 2 diabetes in Japanese men: The Osaka Health Survey. J Hypertens 19: 1209-1215. doi:10.1097/00004872-200107000-00005. PubMed: 11446710.

16. Moher D, Liberati A, Tetzlaff J, Altman DG, Group P (2009) Preferred reporting items for systematic reviews and meta-analyses: the PRISMA statement. PLOS Med 6: e1000097

17. Hoelzel W, Weykamp C, Jeppsson JO, Miedema K, Barr JR et al. (2004) IFCC reference system for measurement of hemoglobin A1c in human blood and the national standardization schemes in the United States, Japan, and Sweden: a method-comparison study. Clin Chem 50: 166-174. doi:10.1373/clinchem.2003.024802. PubMed: 14709644.

18. Ulm K (1990) A simple method to calculate the confidence interval of a standardized mortality ratio (SMR). Am J Epidemiol 131: 373-375. PubMed: 2296988

19. DerSimonian R, Laird N (1986) Meta-analysis in clinical trials. Control Clin Trials 7: 177-188. doi:10.1016/0197-2456(86)90046-2. PubMed: 3802833.

20. Cochran W (1954) The combination of estimates from different experiments. Biometrics 10: 101-129. doi:10.2307/3001666.

21. Higgins JP, Thompson SG, Deeks JJ, Altman DG (2003) Measuring inconsistency in meta-analyses. BMJ 327: 557-560. doi:10.1136/bmj. 327.7414.557. PubMed: 12958120.

22. Begg CB, Mazumdar M (1994) Operating characteristics of a rank correlation test for publication bias. Biometrics 50: 1088-1101. doi: 10.2307/2533446. PubMed: 7786990.

23. Egger M, Davey Smith G, Schneider M, Minder C (1997) Bias in metaanalysis detected by a simple, graphical test. BMJ 315: 629-634. doi: 10.1136/bmj.315.7109.629. PubMed: 9310563

24. Thompson SG (2008) Why and how Sources of Heterogeneity Should be Investigated. Systematic Reviews in Health Care. BMJ Publishing Publishing House Group. pp. 157-175.

25. Harbord RM, Higgins JPT (2008) Meta-regression in Stata. STATA J 8: 493-519.

26. Ogihara T, Nakao K, Fukui T, Fukiyama K, Ueshima K et al. (2008) Effects of candesartan compared with amlodipine in hypertensive patients with high cardiovascular risks: candesartan antihypertensive survival evaluation in Japan trial. Hypertension 51: 393-398. doi: 10.1161/HYPERTENSIONAHA.107.098475. PubMed: 18172059.

27. Noda M, Kato M, Takahashi Y, Matsushita Y, Mizoue T et al. (2010) Fasting plasma glucose and 5-year incidence of diabetes in the JPHC diabetes study - suggestion for the threshold for impaired fasting glucose among Japanese. Endocr J 57: 629-637. doi:10.1507/ endocrj.K10E-010. PubMed: 20508383.

28. Fukagawa K (1998) The background behind the incidence of diabetes in patient with obesity in the Oita Prefecture. J Japan Soc Study Obesity 4: 38-43

29. Takahashi K, Uchiyama H, Yanagisawa S, Kamae I (2006) The logistic regression and ROC analysis of group-based screening for predicting diabetes incidence in four years. Kobe $\mathrm{J}$ Med Sci 52: 171-180. PubMed: 17329955

30. Akiyama T, Kanda K, Yoshikawa H, Hirohata Y, Kihara Y et al. (2002) a-Glucosidase inhibitor prevents the development of impaired glucose tolerance in type 2 diabetes. J Japan Diab Soc 45: 791-795 (in Japanese)

31. Ishida S, Ito C Murakami F, Horikawa C, Gennai N et al (2004) Prevention of type 2 diabetes mellitus by changing lifestyle among high risk persons: The Diabetes Prevention Program of Hiroshima (DPPH) Design and one-year interm report on feasibility. J Japan Diab Soc 47: 707-713 (in Japanese)

32. Kadowaki T, Miyake $\mathrm{Y}$, Hagura $\mathrm{R}$, Akanuma $\mathrm{Y}$, Kajinuma $\mathrm{H}$ et al. (1984) Risk factors for worsening to diabetes in subjects with impaired glucose tolerance. Diabetologia 26: 44-49. PubMed: 6368299.

33. Kawahara T, Takahashi K, Inazu T, Arao T, Kawahara C et al. (2008) Reduced progression to type 2 diabetes from impaired glucose tolerance after a 2-day in-hospital diabetes educational program: the Joetsu Diabetes Prevention Trial. Diabetes Care 31: 1949-1954. doi: 10.2337/dc07-2272. PubMed: 18591401

34. Kosaka K, Noda M, Kuzuya T (2005) Prevention of type 2 diabetes by lifestyle intervention: a Japanese trial in IGT males. Diabetes Res Clin Pract 67: 152-162. doi:10.1016/j.diabres.2004.06.010. PubMed: 15649575

35. Matsumoto K, Ozaki M, Fujita N, Miyake S (2005) Insulin resistance and metabolic syndrome contribute significantly to the transition of borderline glucose tolerance to type 2 diabetes mellitus. J Japan Diab Soc 48: 849-854 (in Japanese)

36. Saito T, Watanabe M, Nishida J, Izumi T, Omura M et al. (2011) Lifestyle modification and prevention of type 2 diabetes in overweight Japanese with impaired fasting glucose levels: a randomized controlled trial. Arch Intern Med 171: 1352-1360. doi:10.1001/archinternmed. 2011.275. PubMed: 21824948.

37. Sakane N, Sato J, Tsushita K, Tsujii S, Kotani K et al. (2011) Prevention of type 2 diabetes in a primary healthcare setting: threeyear results of lifestyle intervention in Japanese subjects with impaired glucose tolerance. BMC Public Health 11: 40. doi: 10.1186/1471-2458-11-40. PubMed: 21235825.

38. Satoh M, Orisaka M (2006) A retrospective study on the development of diabetes mellitus in the individuals with impaired fasting glucose for four years. J Prevent Med 419: 48-50 (in Japanese)

39. Toshihiro M, Saito K, Takikawa S, Takebe N, Onoda T et al. (2008) Psychosocial factors are independent risk factors for the development of Type 2 diabetes in Japanese workers with impaired fasting glucose and/or impaired glucose tolerance. Diabet Med 25: 1211-1217. doi: 10.1111/j.1464-5491.2008.02566.x. PubMed: 19046200

40. Arase Y, Suzuki F, Ikeda K, Kumada H, Tsuji H et al. (2009) Multivariate analysis of risk factors for the development of type 2 diabetes in nonalcoholic fatty liver disease. J Gastroenterol 44: 1064-1070. doi:10.1007/s00535-009-0091-1. PubMed: 19533014.

41. Ito C, Maeda R, Nakamura K, Sasaki H (1996) Prediction of diabetes mellitus (NIDDM). Diabetes Res Clin Pract 34 Suppl: S7-11. doi: 10.1016/S0168-8227(96)01298-3. PubMed: 9015664.

42. Kawazu S (1998) Incidence of type 2 diabetes mellitus (non-insulindependent diabetes mellitus) by the levels of fasting plasma glucose, 2 hour plasma glucose and insulin response to glucose during $75 \mathrm{~g}$ OGTT. J Japan Diab Soc Supplement 2: A53-56 (in Japanese)

43. Seki A, Takigawa T, Ito T, Fukuoka E, Takahashi K et al. (2002) Obesity and the risk of diabetes mellitus in middle-aged Japanese men. Acta Med Okayama 56: 255-260. PubMed: 12530509.

44. Sohma M, Mutoh E, Kohgo Y (2007) Effects of exercise on the blood sugar, blood lipid profile, risk of diabetes and risk of cerebral infarction: The Higashikagura study. J Japan Diab Soc 50: 297-301 (in Japanese)

45. Takahashi M, Kaji K, Togashi A, Ogino Y, Shibosawa T et al. (2001) Usefulness of paired estimation of fating plasma glucose and $\mathrm{HbA} 1 \mathrm{c}$ : A long-term follow-up study of screened nondiabetic subjects. J Japan Diab Soc 44: 745-750 (in Japanese)

46. Takashina S (1996) The investigation of diabetes prevention. Nouson no Kenkou Hukushi series 65: 11-19 (in Japanese)

47. Iso H, Date C, Wakai K, Fukui M, Tamakoshi A et al. (2006) The relationship between green tea and total caffeine intake and risk for self-reported type 2 diabetes among Japanese adults. Ann Intern Med 144: 554-562. doi:10.7326/0003-4819-144-8-200604180-00005. PubMed: 16618952

48. Oba S, Nagata C, Nakamura K, Fujii K, Kawachi T et al. (2010) Consumption of coffee, green tea, oolong tea, black tea, chocolate snacks and the caffeine content in relation to risk of diabetes in Japanese men and women. $\mathrm{Br} \mathrm{J}$ Nutr 103: 453-459. doi:10.1017/ S0007114509991966. PubMed: 19818197.

49. Doi Y, Ninomiya T, Hirakawa Y, Takahashi O, Mukai N et al. (2013) Angiopoietin-like protein 2 and risk of type 2 diabetes in a general Japanese population: the hisayama study. Diabetes Care 36: 98-100. doi:10.2337/dc12-0166. PubMed: 22966088.

50. Fujita M, Ueno K, Hata A (2009) Effect of obesity on incidence of type 2 diabetes declines with age among Japanese women. Exp Biol Med (Maywood) 234: 750-757. doi:10.3181/0810-RM-292. PubMed: 19429850.

51. Kameda W, Daimon M, Oizumi T, Jimbu Y, Kimura M et al. (2005) Association of decrease in serum dehydroepiandrosterone sulfate levels with the progression to type 2 diabetes in men of a Japanese population: the Funagata Study. Metabolism 54: 669-676. doi:10.1016/ j.metabol.2004.12.011. PubMed: 15877298

52. Kawakami N, Takatsuka N, Shimizu H, Ishibashi H (1999) Depressive symptoms and occurrence of type 2 diabetes among Japanese men. Diabetes Care 22: 1071-1076. doi:10.2337/diacare.22.7.1071. PubMed: 10388970.

53. Maegawa $\mathrm{H}$, Hidaka $\mathrm{H}$, Okayama $\mathrm{A}$, Kikkawa $\mathrm{R}$, Kobayashi $\mathrm{M}$ et al. (1992) Risk factors for non-insulin dependent diabetes mellitus in a rural Japanese population - Incidence and risk factors-. J Japan Diab Soc 35: 241-248 (in Japanese)

54. Nakanishi $N(2000)$ The effect of cigarette smoking on the incidence of diabetes: an investigation among late middle age male workers. J Health Welfare Stat 47: 28-33 (in Japanese)

55. Nakano A (1996) The epidemiological study of risk factors for noninsulin-dependent diabetes mellitus. Fukushima J Med Sci 46: 39-46 (in Japanese)

56. Tanabe N, Saito K, Yamada Y, Takasawa T, Seki N et al. (2009) Risk assessment by post-challenge plasma glucose, insulin response ratio, and other indices of insulin resistance and/or secretion for predicting 
the development of type 2 diabetes. Intern Med 48: 401-409. doi: 10.2169/internalmedicine.48.1325. PubMed: 19293537.

57. Yoshinaga H, Kosaka K (1999) Heterogeneous relationship of early insulin response and fasting insulin level with development of noninsulin-dependent diabetes mellitus in non-diabetic Japanese subjects with or without obesity. Diabetes Res Clin Pract 44: 129-136. doi: 10.1016/S0168-8227(99)00019-4. PubMed: 10414932.

58. Fukui M, Tanaka M, Toda H, Senmaru T, Sakabe K et al. (2011) Risk factors for development of diabetes mellitus, hypertension and dyslipidemia. Diabetes Res Clin Pract 94: e15-e18. doi:10.1016/ j.diabres.2011.07.006. PubMed: 21802759

59. Hayashino $\mathrm{Y}$, Fukuhara S, Okamura T, Tanaka T, Ueshima $\mathrm{H}$ et al. (2011) High oolong tea consumption predicts future risk of diabetes among Japanese male workers: a prospective cohort study. Diabet Med 28: 805-810. doi:10.1111/j.1464-5491.2011.03239.x. PubMed: 21244473.

60. Heianza Y, Hara S, Arase Y, Saito K, Fujiwara K et al. (2011) HbA1c $5.7-6.4 \%$ and impaired fasting plasma glucose for diagnosis of prediabetes and risk of progression to diabetes in Japan (TOPICS 3): a longitudinal cohort study. Lancet 378: 147-155. doi:10.1016/ S0140-6736(11)60472-8. PubMed: 21705064.

61. Inoue K, Matsumoto M, Kobayashi Y (2007) The combination of fasting plasma glucose and glycosylated hemoglobin predicts type 2 diabetes in Japanese workers. Diabetes Res Clin Pract 77: 451-458. doi: 10.1016/j.diabres.2007.01.024. PubMed: 17346846.

62. Kato M, Noda M, Suga H, Matsumoto M, Kanazawa $Y$ (2009) Fasting plasma glucose and incidence of diabetes - implication for the threshold for impaired fasting glucose: results from the population-based Omiya MA cohort study. J Atheroscler Thromb 16: 857-861. PubMed: 20032586.

63. Li $\mathrm{Y}$, Yatsuya $\mathrm{H}$, Iso $\mathrm{H}$, Toyoshima H, Tamakoshi $\mathrm{K}$ (2012) Inverse relationship of serum adiponectin concentration with type 2 diabetes mellitus incidence in middle-aged Japanese workers: six-year followup. Diabetes/Metab Res Rev 28: 349-356. doi:10.1002/dmrr.2277. PubMed: 22228701

64. Muraki I, Tanigawa T, Yamagishi K, Sakurai S, Ohira T et al. (2010) Nocturnal intermittent hypoxia and the development of type 2 diabetes: the Circulatory Risk in Communities Study (CIRCS). Diabetologia 53: 481-488. doi:10.1007/s00125-009-1616-0. PubMed: 19946661.

65. Nagaya T, Yoshida H, Takahashi H, Kawai M (2010) Resting heart rate and blood pressure, independent of each other, proportionally raise the risk for type-2 diabetes mellitus. Int J Epidemiol 39: 215-222. doi: 10.1093/ije/dyp229. PubMed: 19564246.

66. Nakanishi N, Suzuki K, Tatara K (2004) Serum gammaglutamyltransferase and risk of metabolic syndrome and type 2 diabetes in middle-aged Japanese men. Diabetes Care 27: 1427-1432. doi:10.2337/diacare.27.6.1427. PubMed: 15161799.

67. Nomura K, Inoue K, Akimoto K (2012) A two-step screening, measurement of $\mathrm{HbA1c}$ in association with FPG, may be useful in predicting diabetes. PLOS ONE 7: e36309. doi:10.1371/journal.pone. 0036309. PubMed: 22558430.

68. Ohnishi H, Saitohi S, Takagii S, Katohi N, Chibai Y et al. (2006) Incidence of type 2 diabetes in individuals with central obesity in a rural Japanese population: the Tanno and Sobetssu study: response to Oda. Diabetes Care 29: 1989. doi:10.2337/dc06-0874. PubMed: 16873828.

69. Okada K, Furusyo N, Sawayama Y, Kanamoto Y, Murata M et al. (2010) Prevalence and risk factors for diabetes: a ten year follow-up study of the Yaeyama district of Okinawa. Fukuoka Igaku Zasshi 101: 215-224. PubMed: 21375144.

70. Sairenchi T, Iso H, Nishimura A, Hosoda T, Irie F et al. (2004) Cigarette smoking and risk of type 2 diabetes mellitus among middle-aged and elderly Japanese men and women. Am J Epidemiol 160: 158-162. doi: 10.1093/aje/kwh183. PubMed: 15234937.

71. Sakurai M, Nakamura K, Miura K, Takamura T, Yoshita K et al. (2012) Dietary glycemic index and risk of type 2 diabetes mellitus in middleaged Japanese men. Metabolism 61: 47-55. doi:10.1016/j.metabol. 2011.05.015. PubMed: 21803381.

72. Sanada H, Yokokawa H, Yoneda M, Yatabe J, Sasaki Yatabe M et al. (2012) High body mass index is an important risk factor for the development of type 2 diabetes. Intern Med 51: 1821-1826. doi: 10.2169/internalmedicine.51.7410. PubMed: 22821094.

73. Sato KK, Hayashi T, Harita N, Koh H, Maeda I et al. (2012) Relationship between drinking patterns and the risk of type 2 diabetes: the Kansai Healthcare Study. J Epidemiol Community Health 66: 507-511. doi:10.1136/jech.2010.109777. PubMed: 21131305.

74. Sawada SS, Lee IM, Naito H, Noguchi J, Tsukamoto K et al. (2010) Long-term trends in cardiorespiratory fitness and the incidence of type 2 diabetes. Diabetes Care 33: 1353-1357. doi:10.2337/dc09-1654. PubMed: 20215460

75. Tanabe N, Seki N, Aizawa Y, Suzuki H (2009) Association of diagnostic components of metabolic syndrome with risk of developing diabetes mellitus: Is obesity necessary for prediction? JPN J Cardiovasc Dis Prev 44: 152-160 (in Japanese)

76. Totsuka K, Maeno T, Saito K, Kodama S, Asumi M et al. (2011) Selfreported fast eating is a potent predictor of development of impaired glucose tolerance in Japanese men and women: Tsukuba Medical Center Study. Diabetes Res Clin Pract 94: e72-e74. doi:10.1016/ j.diabres.2011.08.015. PubMed: 21908066.

77. Oba S, Noda M, Waki K, Nanri A, Kato M et al. (2012) Smoking cessation increases short-term risk of type 2 diabetes irrespective of weight gain: the Japan Public Health Center-Based Prospective Study. PLOS ONE 7: e17061. doi:10.1371/journal.pone.0017061. PubMed: 22879858.

78. Kato M, Noda M, Inoue M, Kadowaki T, Tsugane S et al. (2009) Psychological factors, coffee and risk of diabetes mellitus among middle-aged Japanese: a population-based prospective study in the JPHC study cohort. Endocr J 56: 459-468. doi:10.1507/ endocrj.K09E-003. PubMed: 19270421.

79. Waki K, Noda M, Sasaki S, Matsumura Y, Takahashi Y et al. (2005) Alcohol consumption and other risk factors for self-reported diabetes among middle-aged Japanese: a population-based prospective study in the JPHC study cohort I. Diabet Med 22: 323-331. doi:10.1111/j. 1464-5491.2004.01403.x. PubMed: 15717882

80. Wada K, Yatsuya H, Ouyang P, Otsuka R, Mitsuhashi H et al. (2009) Self-reported medical history was generally accurate among Japanese workplace population. J Clin Epidemiol 62: 306-313. doi:10.1016/ j.jclinepi.2008.04.006. PubMed: 18774692.

81. Beckles GL, Zhu J, Moonesinghe R, Centers for Disease C (2011) Prevention. Diabetes - United States, 2004, and 2008 MMWR Surveill Summ 60 Suppl: 90-93

82. Villegas R, Shu X-O, Li H, Yang G, Matthews CE et al. (2006) Physical activity and the incidence of type 2 diabetes in the Shanghai women's health study. Int J Epidemiol 35: 1553-1562. doi:10.1093/ije/dyl209. PubMed: 16984936.

83. González EL, Johansson S, Wallander MA, Rodríguez LA (2009) Trends in the prevalence and incidence of diabetes in the UK: 1996-2005. J Epidemiol Community Health 63: 332-336. doi:10.1136/ jech.2008.080382. PubMed: 19240084.

84. Cugati S, Wang JJ, Rochtchina E, Mitchell P (2007) Ten-year incidence of diabetes in older Australians: the Blue Mountains Eye Study. Med J Aust 186: 131-135. PubMed: 17309402

85. Rimm EB, Chan J, Stampfer MJ, Colditz GA, Willett WC (1995) Prospective study of cigarette smoking, alcohol use, and the risk of diabetes in men. BMJ 310: 555-559. doi:10.1136/bmj.310.6979.555. PubMed: 7888928.

86. Folsom AR, Kushi LH, Anderson KE, Mink PJ, Olson JE et al. (2000) Associations of general and abdominal obesity with multiple health outcomes in older women: the lowa Women's Health Study. Arch Intern Med 160: 2117-2128. doi:10.1001/archinte.160.14.2117. PubMed: 10904454.

87. Yatsuya H, Yamagishi $\mathrm{K}$, Iso $\mathrm{H}$ (2011) Adiposity and risk of cardiovascular diseases in Japan: secular trend, individual level associations and causal pathway - implications for the prevention of cardiovascular diseases in societies with rapid economic development. EPMA J 2: 65-73. doi:10.1007/s13167-011-0071-4. PubMed: 23199128.

88. Ministry of Health, Labour and Welfare (2012) The second. Health Japan 21 project. Available: http://www.mhlw.go.jp/bunya/kenkou/dl/ kenkounippon21 02.pdf. Accessed 27 June 2013 